\title{
EVALUATION OF THE DIAMETER OF THE LUMBAR VERTEBRAL CANAL USING COMPUTED TOMOGRAPHY IN MEXICAN POPULATION
}

\author{
AVALIAÇÃO DO DIÂMETRO DO CANAL VERTEBRAL LOMBAR POR TOMOGRAFIA \\ COMPUTADORIZADA NA POPULAÇÃO MEXICANA
}

\author{
EVALUACIÓN DEL DIÁMETRO DEL CONDUCTO LUMBAR POR TOMOGRAFÍA \\ COMPUTARIZADA EN POBLACIÓN MEXICANA
}

Roxana Torres Castellanos ${ }^{1}$, Roberto Alfonso Martínez Medel ${ }^{1}$, Emilio Barbarín Rodríguez ${ }^{1}$

1. Servicio de Traumatología y Ortopedia, Hospital Central Cruz Roja Mexicana, Polanco, Mexico, D.F

\begin{abstract}
Objective: To conduct a descriptive study to find measures of central tendency in the vertebral bodies L3, L4, and L5 in the Mexican population. Methods: Fifty patients were considered, 33 male and 17 female, aged between 30 and 55 years. Measurements were performed at the levels L3, L4 and L5 taking the interpedicular distance (A), mid-sagittal diameter (B), anteroposterior distance (AP) and the depth of lateral recess $(\mathrm{R})$ in axial 2-mm sections of CT scans (Somaton Emotion, SIEMENS, 2 sections) in a Mexican population with healthy vertebral bodies, with no history of lumbar pathology. Results: Overall, the measures obtained were mean interpedicular distance of 22.80 in L3, range of 16.34/28.72. In L4, mean of 23.83, range of 17.62/27.92. In L5, mean of 25.28, range of 21.88/31.29. Conclusions: This study managed to make a database that did not exist in Mexico, using measures of central tendency. Therefore, it opens the way for it to be possible, in future studies, to identify predictive factors or even developing implants.
\end{abstract}

Keywords: Spine; Lumbosacral region; Magnetic resonance imaging.

\section{RESUMO}

Objetivo: Realizar um estudo descritivo para encontrar medidas de tendência central nos corpos vertebrais $L 3, L 4$ e $L 5$ na população mexicana. Métodos: Foram considerados 50 pacientes, 33 homens e 17 mulheres, com idades entre 30 e 55 anos. Foram realizadas medidas no nível de L3, L4 e L5, tomando-se a distância interpedicular (A), o diâmetro mediossagital (B), a distância anteroposterior (AP) e a profundidade do recesso lateral (R) em cortes axiais de tomografia computadorizada (tomógrafo Somaton Emotion, SIEMENS, 2 cortes) em uma população mexicana com corpos vertebrais saudáveis, sem história prévia de patologia lombar. Resultados: Obteve-se, no geral, distância interpedicular média de 22,80 em L3, com faixa de 16,34/28,72. Em L4, média de 23,83, faixa de 17,62/27,92. Em L5, média de 25,28, faixa de 21,88/31,29. Conc/usões: 0 presente estudo conseguiu fazer um banco de dados que não existia no país usando medidas de tendência central. Desse modo, abre-se o caminho para que, em estudos posteriores, seja possível identificar fatores preditivos ou até mesmo o desenvolvimento de implantes.

Descritores: Coluna vertebral; Região lombossacral; Imagem por ressonância magnética.

\section{RESUMEN}

Objetivo: Realizar un estudio descriptivo para buscar medidas de tendencia central en los cuerpos vertebrales $L 3$, L4 y L5 en población mexicana Métodos: Fueron considerados 50 pacientes, 33 hombres y 17 mujeres, con edades entre 30 y 55 años. Se realizaron mediciones a nivel de L3, L4, L5, tomando la distancia interpedicular (A), el diámetro mediosagital (B), la distancia anteroposterior (AP) y profundidad de receso lateral $(R)$ en cortes axiales de tomografía axial computarizada de $2 \mathrm{~mm}$ (tomógrafo Somaton Emotion, SIEMENS, 2 cortes) en una población mexicana con cuerpos vertebrales sanos, sin antecedente previo de patología lumbar. Resultados: Se obtuvo en general una distancia interpedicular media de 22,80 en L3, con un rango de 16,34/28,72. En L4, media de 23,83, rango de 17,62/27,92. En L5, media de 25,28, rango de 21,88/31,29. Conclusiones: El presente estudio logró realizar una base de datos no existente en el país utilizando medidas de tendencia central. De este modo, se abre camino para que en estudios posteriores se logre determinar factores predictivos o inclusive el desarrollo de implantes.

Descriptores: Columna vertebral; Región lumbosacra; Imagen por resonancia magnética.

\section{INTRODUCTION}

Precise information about the dimensions of the lumbar vertebrae is crucial for the spine surgeon, both for the clinical radiological evaluation and for surgical procedures. ${ }^{1}$ There are diseases that affect the neuronal structures and cause radicular symptoms. When there is stenosis at the lumbar canal or intervertebral level, the neuronal structures can be affected, causing symptoms like low back pain or radicular pain. ${ }^{2}$

Low back pain is one of the major causes of disability, deterioration of the quality of life, and high hospital costs. In the United States of America, an annual cost of approximately $\$ 50$ billion is reported. ${ }^{3}$ This is found in patients with an average age of 45 years.

Approximately $1 \%$ of the population will experience chronic disability because of it.

The structures of the lumbar canal are considered complex to 
diagnose and treat, so knowledge of their anatomy is critically important in pathology. ${ }^{4}$

Stenosis of the lumbar canal usually involves the central spinal canal, the lateral recesses, and the intervertebral foramens. ${ }^{5}$ Pathological changes occur at these levels.

Spinal measurements are generally incomplete. ${ }^{2}$ There are bibliographical references that report some values; however, they are usually focused on a specific population. ${ }^{6}$

There are maximum and minimum measurements that we plan to use in this study in order to populate an initial database of the average in the Mexican population wit hout current lumbar symptoms or associated disease.

The main objective of this study is to describe measurements of the lumbar spine, specifically in L3, L4, and L5, from axial slices of computed axial tomography. This study was conducted with a Mexican population between 30 and 55 years of age with no previous symptoms.

\section{MATERIAL AND METHODS}

Fifty patients were included, all Mexican, with no record of previous lumbar disease, symptoms, or associated comorbidities at the levels selected. Thirty-three were men, 17 were women, all of them between the ages of 30 and 55 .

The following exclusion criteria were used:

Younger than 30 or older than 55 years of age, prior degenerative lumbar disease, associated lumbar spine symptoms, already known comorbidities or information about fractures at this level, nationality other than Mexican.

The following inclusion criteria were used: Age between 30 and 55 years, Mexican nationality, asymptomatic, without prior comorbidity, with computed tomography.

The measurements of L3, L4, and L5 were taken in $2 \mathrm{~mm}$ axial slices of computed axial tomography (Somaton Emotion 2-slice, SIEMENS) from a Mexican population with healthy vertebral bodies and without previous history of lumbar disease.

Parameters studied: levels L3, L4, L5, measuring the interpedicular distance $(A)$, the mid-sagittal diameter $(B)$, the anteroposterior distance (AP), and the depth of the lateral recess (R). ${ }^{5}$

Measures of central tendency were used, based on the data obtained. The study was approved by the ethics committee of the Hospital Central de Cruz Roja Mexicana. Delegación Polanco, México. D.F. on May 12, 2015.

\section{RESULTS}

The following values of normality were obtained from the 50 patients studied, all with healthy vertebrae and without previous lumbar disease, with the help of measures of central tendency. (Tables 1, 2, and 3)

Table 1. Measures of Central Tendency L3.

\begin{tabular}{c|c|c|c|c}
\hline \multicolumn{5}{|c}{ Vertebra L3 } \\
\hline & $\begin{array}{c}\text { Interpedicu- } \\
\text { Iar distance }\end{array}$ & $\begin{array}{c}\text { Midsagittal } \\
\text { diameter }\end{array}$ & $\begin{array}{c}\text { Anteroposte- } \\
\text { rior distance }\end{array}$ & $\begin{array}{c}\text { Depth of } \\
\text { the lateral } \\
\text { recess }\end{array}$ \\
\hline Mode & 22.85 & 15.83 & 7 & 16.47 \\
\hline Median & 22.85 & 15.83 & 7.69 & 19.86 \\
\hline Mean & 22.80133333 & 16.24044444 & 7.762666667 & 20.59288889 \\
\hline Standard deviation & 2.595919525 & 2.417915101 & 1.308017931 & 4.106924652 \\
\hline Range & $16.34-28.72$ & $12.36-22.79$ & $5.31-9.97$ & $14.66-31.96$ \\
\hline
\end{tabular}

Table 2. Measures of Central Tendency L4.

\begin{tabular}{c|c|c|c|c}
\hline & $\begin{array}{c}\text { Interpedicu- } \\
\text { lar distance }\end{array}$ & $\begin{array}{c}\text { Midsagittal } \\
\text { diameter }\end{array}$ & $\begin{array}{c}\text { Anteropos- } \\
\text { terior dis- } \\
\text { tance }\end{array}$ & $\begin{array}{c}\text { Depth of } \\
\text { the lateral } \\
\text { recess }\end{array}$ \\
\hline Moda & 24.76 & 15.25 & 5.28 & 19.53 \\
\hline Mediana & 23.3 & 15.47 & 6.69 & 18.43 \\
\hline Media & 23.83702703 & 15.69 & 6.922162162 & 18.97540541 \\
\hline $\begin{array}{c}\text { Desviacion es- } \\
\text { tandar }\end{array}$ & 2.465520978 & 2.103222395 & 1.339880043 & 3.153022883 \\
\hline Rango & $17.62-27.92$ & $11.56-20.26$ & $5.07-9.89$ & $11.35-27.36$ \\
\hline
\end{tabular}

Table 3. Measures of Central Tendency L5

\begin{tabular}{c|c|c|c|c}
\hline & $\begin{array}{c}\text { Interpedicu- } \\
\text { lar distance }\end{array}$ & $\begin{array}{c}\text { Midsagittal } \\
\text { diameter }\end{array}$ & $\begin{array}{c}\text { Anteropos- } \\
\text { terior dis- } \\
\text { tance }\end{array}$ & $\begin{array}{c}\text { Depth of } \\
\text { the lateral } \\
\text { recess }\end{array}$ \\
\hline Mode & 22.49 & 18.33 & 5.48 & 18.04 \\
\hline Median & 25.94 & 16.86 & 6.42 & 18.98 \\
\hline Mean & 25.2872222 & 17.26 & 6.57111111 & 19.4983333 \\
\hline Standard deviation & 3.0556636 & 2.93342803 & 1.17390193 & 3.38688517 \\
\hline Range & $21.88-31.29$ & $13.94-23.70$ & $5.35-10.00$ & $14.14-25.26$ \\
\hline
\end{tabular}

\section{DISCUSSION}

Low back pain is one of the main reasons for general orthopedic and spine surgeon consultations. ${ }^{7}$ It is a common cause of disability in the working population, creating an extremely significant economic deficit in all states. ${ }^{8}$ Using the measurements of the lumbar canal in Mexican patients with healthy vertebrae, it is possible to establish a parameter of normality. A data base that did not previously exist for the Mexican population was created for comparison with other populations and to observe the variability between them, since all patients had healthy vertebrae and no previous history of lumbar disease. Using this we plan to encourage the enrichment of this information, so that in the future, using a larger population, it might even be possible to achieve something more ambitious like being able to predict diseases that involve the degeneration of the vertebrae and their structures and thus, design implants specifically for the Mexican population.

\section{CONCLUSION}

This study created a data base that did not exist in the country using measures of central tendency and opened the door for future studies to determine predictive factors and even develop new implants or improve the existing ones.

\section{ACKNOWLEDGEMENTS}

To the Hospital Central de Cruz Roja Polanco, for permission to use the database of lumbar spine computed tomographies.

All authors declare that there are no conflicts of interest regarding this article.

AUTHORS' CONTRIBUTION: Each author made significant contributions to the development of this manuscript: RT wrote the abstract, provided translations, wrote the materials and methods section, and contributed to the discussion. RM built the statistical tables, wrote the results, and contributed to the discussion. EB prepared the conclusions based on the results and contributed to the discussion.

\section{REFERENCES}

1. Steurer J, Roner S, Gnannt R, Hodler J; LumbSten Research Collaboration. Quantitative radiologic criteria for the diagnosis of lumbar spinal stenosis: a systematic literature review. BMC Musculoskelet Disord. 2011;12:175

2. Schizas C, Theumann N, Burn A, Tansey R, Wardlaw D, Smith FW, et al. Qualitative grading of severity of lumbar spinal stenosis based on the morphology of the dural sac on magnetic resonance images. Spine (Phila Pa 1976). 2010;35(21):1919-24.

3. Miabi Z, Mashrabi O. Evaluation of lumbar canal diameter and areas by computed tomography. Res J Biol Sci. 2009;4(4):494-8
4. Herkowitz HN, Garfin SR, Eismont FJ, Bell GR, Balderton RA. Rothman-Simeone the spine. 6th. ed. Philadelphia: Saunders; 2011.

5. Aly T, Amin O. Geometrical dimensions and morphological study of the lumbar spinal canal in the normal Egyptian population. Orthopedics. 201336(2):e229-34

6. Pai VS, Kumar B. Lumbar canal measurements. J Orthop Surg. 1995;3(2):31-4

7. Muhammad Zahoor Janjua, Fida Muhammad. Measurements of the normal adult lumbar spinal canal. JPMA. 1989;39:264-8.

8. Chatha DS, Schweit ME. MRI criteria of developmental lumbar spinal stenosis revisited. Bull NYU Hosp Joint Dis. 2011;69(4):303 